\title{
Granular cell tumour of the bile duct in association with intrahepatic bile duct adenomas
}

F SCHWEIGER MD FRCPC FACG, J RADHI MB FRCPC MRCParh, FW COOP MD FRCPC, RW MURPHY MD FRCSC

F SCHWEIGER, J RADHI, FW COOP, RW MURPHY. Granular cell tumour of the bile duct in association with intrahepatic bile duct adenomas. Can J Gastroenterol 1994;8(2):92-96. Granular cell tumour of the extrahepatic biliary tract is a rare benign lesion likely of neurogenic origin. Review of the previously reported cases indicates that almost all patients are female, and the majority is Black. Symptoms usually are those of biliary obstruction or cholecystitis. Surgical resection of the tumour is curative. Intrahepatic bile duct adenoma is another rare benign biliary neoplasm that does not manifest clinically but can be confused with metastatic carcinoma, cholangiocarcinoma or other focal liver lesions at laparotomy or autopsy. The authors report the case of an asymptomatic Caucasian woman with biochemical evidence of liver disease who had a granular cell tumour of the bile duct as well as several intrahepatic bile duct adenomas.

Key Words: Bile duct tumour, Granular cell tumour, Intrahepatic bile duct adenoma

Granulome du canal cholédoque, en association avec un adénome intrahépatique : Rapport de cas et survol de la littérature

RÉSUMÉ : Le granulome du tractus biliaire extra-hépatique est une lésion bénigne susceptible d'avoir une origine neurogène. Le survol des cas recensés à ce jour indique que la plupart des patients sont de sexe féminin et en majorité de race noire. Les symptômes sont habituellement ceux d'une obstruction biliaire ou d'une cholécystite. L'ablation chirurgicale de la tumeur est curative. Le granulome du tractus biliaire intrahépatique est une autre néoplasie biliaire bénigne rare qui n'a pas de manifestations cliniques, mais qui peut être confondue avec un cancer métastatique ou avec un cholangiocarcinome ou une autre lésion hépatique localisée à la laparotomie ou à l'autopsie. Les auteurs rapportent le cas d'une femme de race blanche asymptomatique manifestant des signes biochimiques de maladie hépatique qui présentait un granulome au niveau du canal cholédoque et plusieurs adénomes des voies biliaires intrahépatiques.

Departments of Internal Medicine (Gastroenterology Division), Pathology, Medical Imaging and Surgery, The Moncton Hospital, Moncton, New Brunswick

Correspondence and reprints: Dr Franzjosef Schweiger, 100 Arden Street, Suite 405,

Professional Arts Building, Moncton, New Brunswick E1C 4B7. Telephone (506) 858-844I

Received for publication July 26, 1993. Accepted August 16, 1993
$\mathrm{E}^{x}$ XTRAHEPATIC BILIARY OBSTRUCtion is most often caused by gallstones or malignant tumours. Benign neoplasms of the extrahepatic biliary tree are very uncommon, with the majority being adenomas and papillomas (1).

Granular cell tumour (GCT) involving the biliary tree is exceedingly rare; fewer than 50 cases were reported in the literature up to $1992(2-7)$. GCTs usually cause biliary colic or jaundice and have a predilection for young Black females.

We report the case of a young Caucasian woman who, in the absence of biliary symptoms, was found to have a GCT of the bile duct as well as intrahepatic bile duct adenomas, another form of rare benign biliary neoplasm.

\section{CASE PRESENTATION}

A 34-year-old previously healthy Caucasian woman presented to the emergency department with a threeyear history of tension headaches for which she took up to 25 tablets of acetaminophen ( $325 \mathrm{mg}$ each) per day. She denied any other symptoms such as abdominal pain, jaundice, fever, pruritus or malaise. The physical examination was completely normal. She was prescribed chlordiazepoxide for her headaches with prompt relief. 
A biochemical screen showed the following abnormalities (normal range in brackets): alkaline phosphatase $451 \mathrm{U} / \mathrm{L}$ (39 to 117); aspartate aminotransferase $73 \mathrm{U} / \mathrm{L}$ ( 7 to 32 ); alanine aminotransferase $143 \mathrm{U} / \mathrm{L}$ (0 to 31 ); and gammaglutamyl transferase 702 U/L ( 7 to 32 ). Total bilirubin was 5 $\mu \mathrm{mol} / \mathrm{L}$ (normal 4 to 18 ). An abdominal ultrasound revealed a normal gallbladder and prominent intrahepatic bile ducts. The common duct measured $0.9 \mathrm{~cm}$ in diameter. A solid echogenic lesion, $1.5 \mathrm{~cm}$ in width, was noted to be within the common bile duct (Figure 1).

Endoscopic retrograde cholangiopancreatography demonstrated pancreas divisum and suggested a biliary stricture, which was more clearly demonstrated on a percutaneous transhepatic cholangiogram. The stricture was located at the junction of the common hepatic duct and the cystic duct. The distal common bile duct was normal but there was mild dilation of the biliary radicals proximal to the stricture (Figure 2). At surgery there was a hard $1.5 \mathrm{~cm}$ nodule with surrounding fibrosis

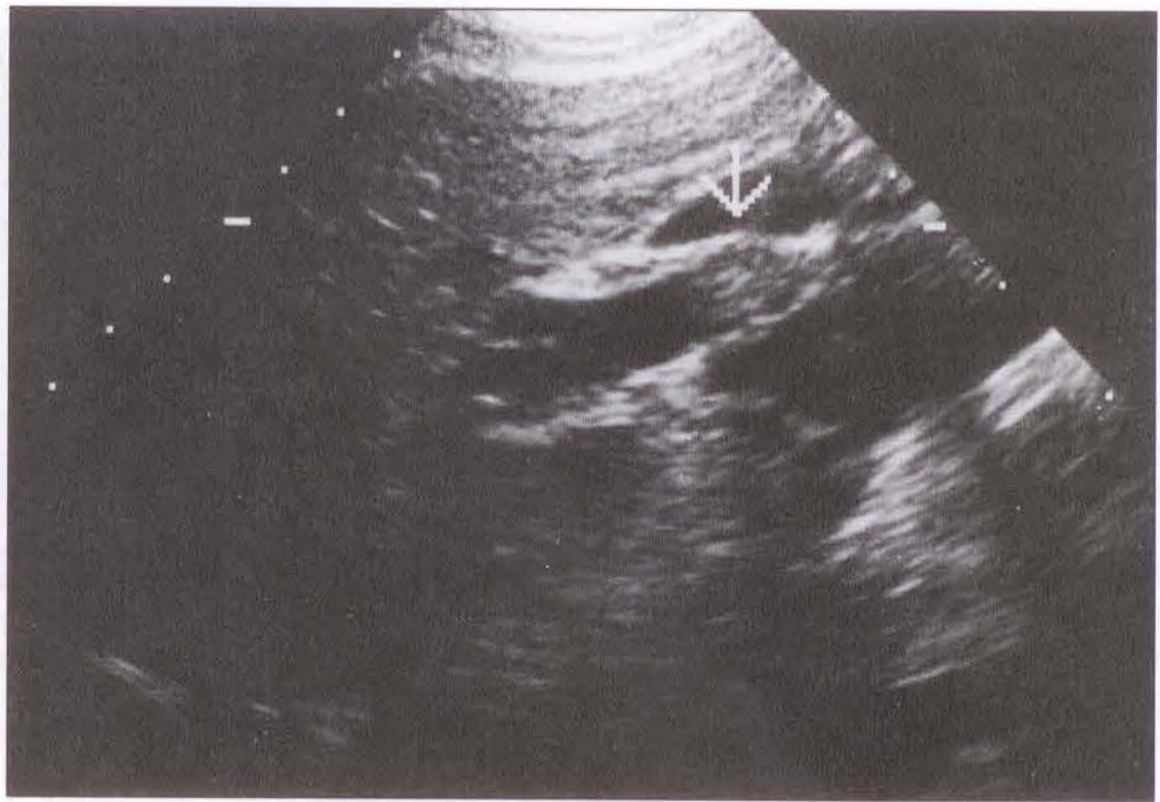

Figure 1) Transabdominal ultrasound demonstrating echogenic solid mass in proximal common bile duct (arrow)

just above the junction of the cystic and common bile ducts. Several small, raised lesions, 3 to $4 \mathrm{~mm}$ in diameter, were noted on the liver surface. These grossly resembled metastatic deposits and were excised. The pancreas was normal. The tumour was resected, cholecystectomy was performed and the biliary tree was reconstructed with a choledochoduodenostomy. The patient's subsequent clinical recovery was uneventful.
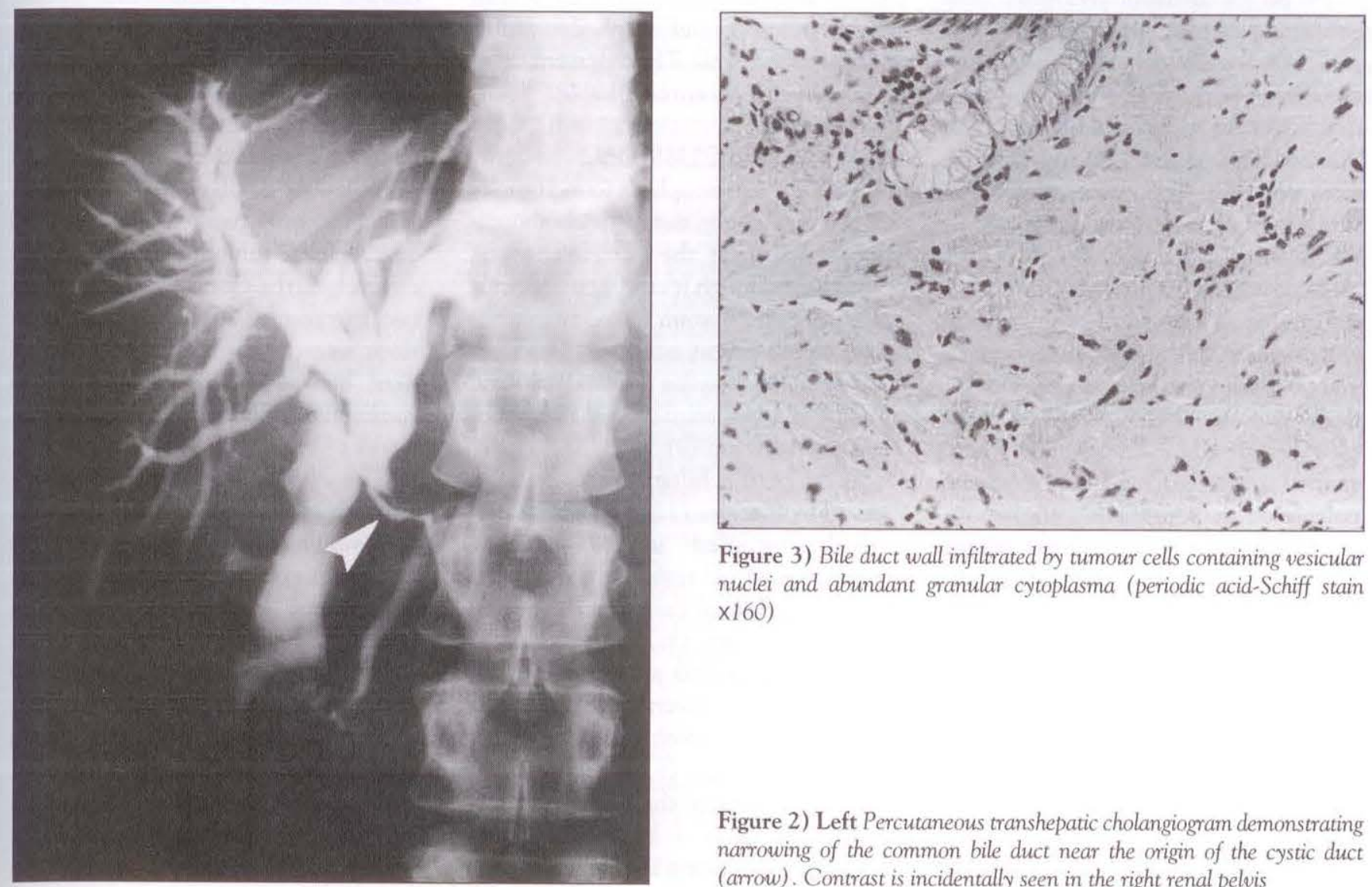

Figure 3) Bile duct wall infiltrated by tumour cells containing vesicular nuclei and abundant granular cytoplasma (periodic acid-Schiff stain $\mathrm{x} 160$ )

Figure 2) Left Percutaneous transhepatic cholangiogram demonstrating narrowing of the common bile duct near the origin of the cystic duct (arrow). Contrast is incidentally seen in the right renal pelvis 


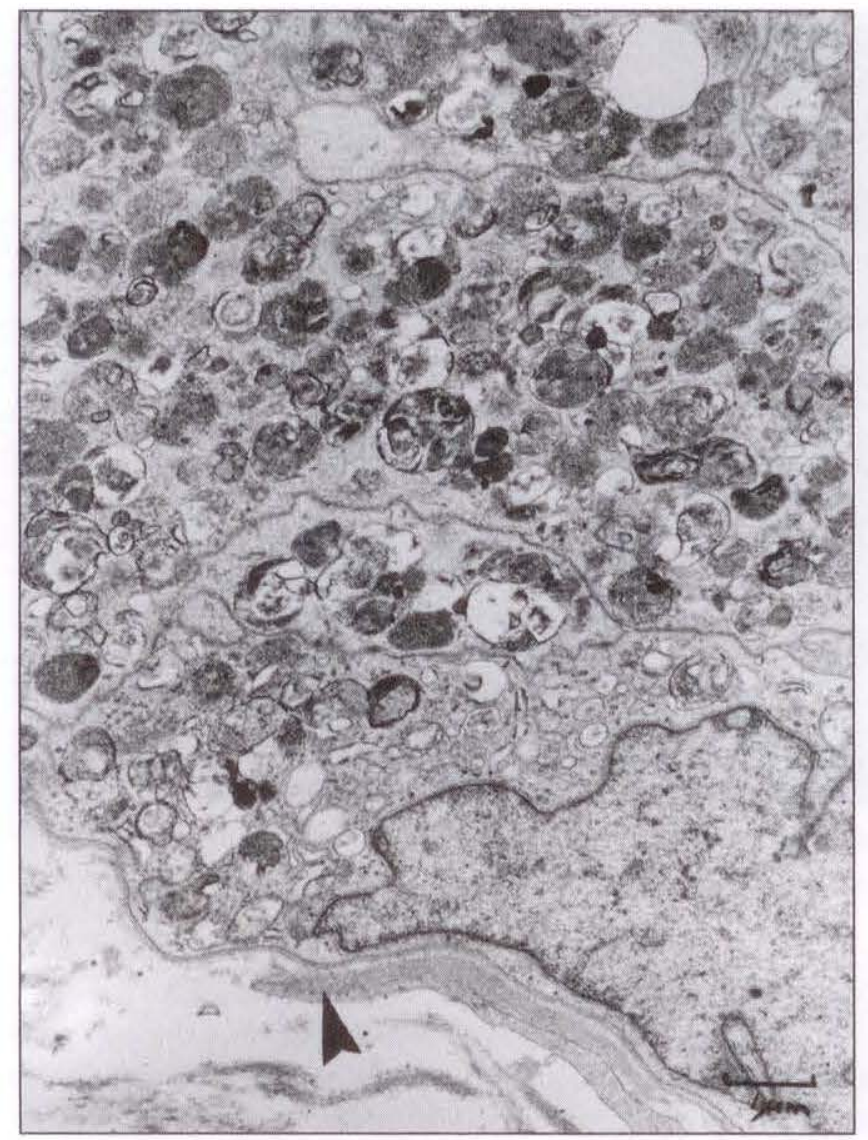

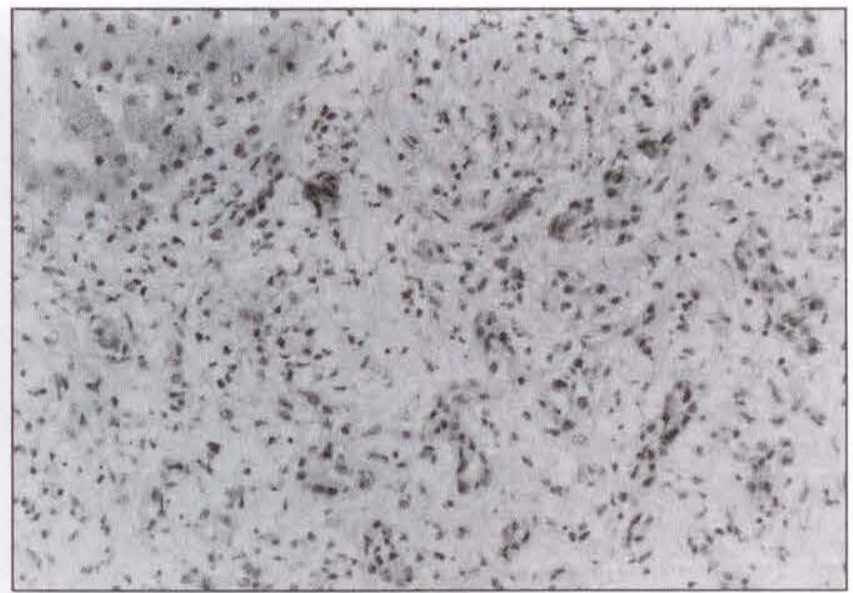

Figure 5) Intrahepatic bile duct adenoma consisting of small ductules surrounded by fibrous stroma (hematoxylin and eosin, x160)

Figure 4) Left Electron micrograph of granular cell demonstrating multiple phagocytic granules and basal lamina (arrow) $(x 15,700)$

\section{PATHOLOGICAL FINDINGS}

A poorly defined yellowish mass measuring $2 \times 1 \mathrm{~cm}$ was present in the wall of the common bile duct close to the entry of the cystic duct. The proximal resection end of the bile duct was dilated. The gallbladder was normal. Two wedges of liver tissue, each measuring $1 \times 1 \mathrm{~cm}$, were mostly replaced by well-circumscribed nodules.

Microscopic examination revealed infiltration of the whole thickness of the common bile duct wall by strands and solid clumps of large eosinophilic finely granular cells with vesicular nuclei (Figure 3). The tumour cells stained positively for S- 100 protein and polyclonal neuron-specific enolase using avidin-biotin immunoperoxidase technique. Electron microscopic examination demonstrated membranebound autophagic granules and distinct basal lamina (Figure 4).

Microscopic examination of the excised surface lesions of the liver revealed a network of ductal structures embedded in a fibrous stroma (Figure 5). The small and inapparent lumina were lined by low columnar epithelial cells lacking nuclear pleomorphism. There was no evidence of bile within the ductules. A mild lymphocytic infiltrate was present. The adjacent liver parenchyma was unremarkable.

\section{DISCUSSION}

GCT is a rare neoplasm found usually in the oral cavity, dermis and subcutaneous tissues of the extremities and chest wall, though it can occur in virtually any organ system (8). Gastrointestinal involvement occurs in less than $5 \%$ of GCTs, may be multicentric and usually is asymptomatic due to its submucosal location (9).

GCTs of the biliary tract, first observed by Coggins (10), have been previously recorded in 45 patients; Butterly et al (2) reviewed 39 patients and six additional cases have appeared in the literature (3-7). Mean age at presentation is 33.6 years (range 11 to 61) for all cases. Twenty-nine of the 45 patients $(64 \%)$ were Black and only three were males $(93 \%$ female incidence). A greater than expected frequency of GCTs - both biliary and extrabiliary - among Black patients has been reported previously $(2,8)$, and the marked female predominance in cases of biliary involvement is striking.

Approximately half of the GCTs is located at or near the junction of the cystic duct, common bile duct and common hepatic ducts. More proximal hepatic duct involvement has been described in only two patients $(2,11)$. In 14 cases, the tumour was confined exclusively to the cystic duct $(2,3)$, and in two instances, isolated gallbladder lesions were seen $(5,12)$. Only one patient had multifocal tumours in the common bile duct, cystic duct and gallbladder (13).

The clinical manifestations generally reflect the location of the tumour. Common bile duct lesions present with pain and/or jaundice in more than $90 \%$ of patients. Pruritus was the initial complaint in a few patients $(6,7,14$ $17)$. When the cystic duct or gallbladder was affected, recurrent biliary colic or acute cholecystitis occurred (2). In one patient, a common bile duct GCT was found incidentally at autopsy (18). This report describes the first living asymptomatic patient with such a le- 
sion (discovered because of an abnormal liver enzyme profile and ultrasound). It is likely that further expansion of the tumour would have led to symptoms pointing towards the biliary tree.

As in the presented case, GCT of the biliary system is an unexpected finding intraoperatively after ultrasound and cholangiography have demonstrated an obstructing lesion or stricture. Cholangiocarcinoma, sclerosing cholangitis or stone disease is the usual preoperative diagnosis.

The tumours grossly are yellowwhite in colour, usually less than $3 \mathrm{~cm}$ in diameter, nodular and not encapsulated. On light microscopy, GCTs consist of large polygonal cells arranged in small nests and cords, and are associated with a variable amount of fibrosis. The round nuclei are centrally located and the eosinophilic cytoplasm contains multiple coarse granules that stain positively with periodic acid-Schiff stain (6).

Abrikossoff (19) initially coined the term 'granular cell myoblastoma', postulating a histogenic origin from striated muscle. However, current knowledge favours Schwann cell derivation. Supporting evidence includes the tumours' close association with nerves and shared immunohistochemical reactivity with antibodies directed against several neural proteins, such as

\section{REFERENCES}

1. Burhans R, Myers RT. Benign neoplasms of the extrahepatic biliary ducts. Am Surg 1971;32:161-6.

2. Butterly LF, Schapiro RH, LaMuraglia GM. Biliary granular cell tumor: a little known curable bile duct neoplasm of young people. Surgery 1988;103:328-34.

3. Hobbiss JH, Hasleton P, Kahn MK, et al. Granular cell myoblastoma of the cystic duct: a case report and review of the literature. J R Coll Surg Edinb 1987;32:117-8.

4. Orenstein HH, Brenner LH, Nay HR. Granular cell myoblastoma of the extrahepatic biliary system. Am J Surg 1984;147:827-31.

5. Yamaguchi K, Kuroki S, Daimaru Y. Granular cell tumor of the gallbladder. Acta Pathol Jpn 1985;35:687-91.

6. Eisen RN, Kirby WM, O'Quinn JL. Granular cell tumor of the biliary tree. A report of two cases and a review of
S-100 protein, neuron-specific enolase and myelin-basic protein. Electron microscopic demonstration of neural elements also lends support to the Schwann cell theory (6). Nevertheless, the noncommitted term 'granular cell tumour' remains widely accepted.

The treatment of biliary GCTs is surgical resection and reanastomosis. Butterly et al (2) observed that in almost all instances these tumours are located in an area where curative excision is readily accomplished and reconstructive procedures - including choledochoduodenostomy, choledochojejunostomy, hepaticoduodenostomy and hepaticojejeunostomy - can be carried out. Intrapancreatic common bile duct involvement may require more extensive surgery, ie, pancreaticoduodenectomy or a simple bypass procedure depending on the clinical circumstances. So far there have been no recurrences after surgical resection of biliary GCTs in all reported cases. Malignant GCTs have been described previously (20), but there are no reports of such tumours involving the biliary tract. Concurrent GCTs at extrabiliary sites have been observed in six patients $(4,7,11,21,22)$. In a recently reported patient with small bowel mesentery and tracheal involvement in addition to a GCT of the bile duct flow cytometric DNA analysis showed that all lesions were diploid

the literature. Am J Surg Pathol

1991;15:460-5.

7. Mullhollan TJ, Ro JY, El-Nagger AK, et al. Granular cell tumor of the biliary tree. Am J Surg Pathol 1992;16:204-5.

8. Lack EE, Worsham GF, Callihan MD, et al. Granular cell tumor: a clinicopathologic study of 110 patients. J Surg Oncol 1980;13:301-16.

9. Fried KS, Arden JL, Gouge TH, et al. Multifocal granular cell tumors of the gastrointestinal tract. Am J Gastroenterol 1984;79:751-5.

10. Coggins RP. Granular cell myoblastoma of the common bile duct. Report of a case with autopsy findings. Arch Pathol 1952;54:398-402.

11. Livolsi VA, Perzin KH, Badder EM, et al. Granular cell tumors of the biliary tract. Arch Pathol 1973;95:13-7.

12. Ishii $T$, Iri $H$, Yamamoto $S$, et al. Granular cell myoblastoma of the gallbladder. Am J Gastroenterol 1977;68:38-44.

13. Aisner SC, Khaneja S, Ramirez O. with low proliferation, supporting multicentricity rather than metastasis (7).

Several intrahepatic bile duct adenomas were discovered in the presented patient intraoperatively. These tumours are exceedingly rare; in a series of 50,000 necropsies only four cases were identified (23). They are more prevalent in males than females, with two-thirds of the reported patients older than age 50. These lesions are virtually always incidental findings during laparotomy or autopsy (24). Most often single and in a subcapsular location, these lesions grossly appear as grey-white firm nodules that measure usually less than $1 \mathrm{~cm}$ in diameter.

Histologically, multiple small bile ducts are surrounded by a fibrous stroma with no evidence of increased cell turnover, mitoses or invasion of adjacent liver (25). The natural history and clinical significance of intrahepatic bile duct adenomas are unknown but rare malignant transformation has not been ruled out (26). Their main significance is their possible confusion with metastatic carcinoma during laparotomy, but histological diagnosis following excisional biopsy is readily accomplished (23). A link between bile duct adenomas with GCTs elsewhere in the biliary tree has not been reported and whether there is a potential association remains open to speculation.

Multiple granular cell tumors of the gallbladder and biliary tree. Report of a case. Arch Pathol Lab Med 1982;106:470-71.

14. Bocquet L, Vissuzaine C, Grossin M, et al. Tumeur a cellules granuleuses des voies biliaires. Arch Anat Cytol Pathol 1980;26:360-4.

15. Mauro MA, Jaques PF. Granular-cell tumors of the esophagus and common bile duct. J Can Assoc Radiol 1981;32:254-6.

16. Penalba C, Vallot T, Cerf M, et al. Les tumeurs a cellules granuleuses des voies biliaires. Ann Chir 1982;36:723-6.

17. Chandrasoma P, Fitzgibbons P. Granular cell myoblastoma of the intrapancreatic common bile duct Cancer 1984;53:2178-82.

18. Whitmore JT, Whitley JP, LaVerde P, et al. Granular cell myoblastoma of the common bile duct Am J Dig Dis 1969;14:516-20.

19. Abrikossoff A. Ueber myome, 
ausgehend von der quergestreiften willkuerlichen muskulatur. Virchows Arch (A) 1926;260:215-33.

20. Khansur T, Balducci L, Tavassoh M. Granular cell tumor. Clinical spectrum of the benign and malignant entity. Cancer 1987;60:220-2.

21. Manstein ME, McBrearty FX, Pellechia PE, et al. Granular cell tumor of the common bile duct. Dig Dis Sci 1981;26:938-42.

22. Assor D. Granular cell myoblastoma involving the common bile duct. Am J Surg 1979;137:673-5.

23. Edmondson HA. Atlas of Tumor Pathology: Tumors of the Liver and Intrahepatic Bile Ducts. Washington: Armed Forces Institute of Pathology, 1958.
24. Ishak KG, Rabin L. Benign tumors of the liver. Med Clin North Am 1975;59:995-1014.

25. Saul SH. Neoplasms of the liver. In: Sternberg SS, ed. Diagnostic Surgical Pathology, vol 2. New York: Raven Press, 1989:1183.

26. Foucar E. Bile duct adenoma. Arch Pathol Lab Med 1985;109:590. (Lett) 


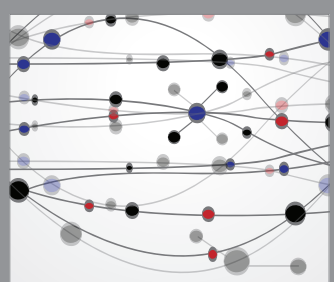

The Scientific World Journal
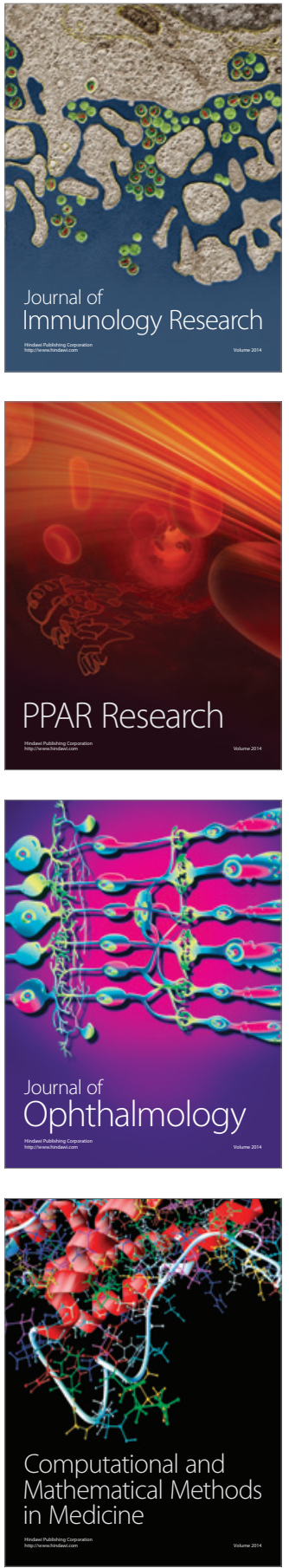

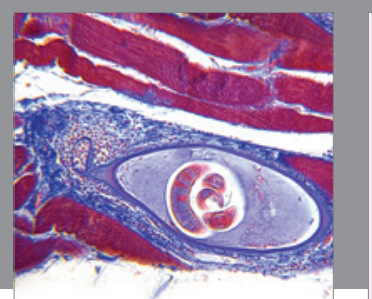

Gastroenterology Research and Practice

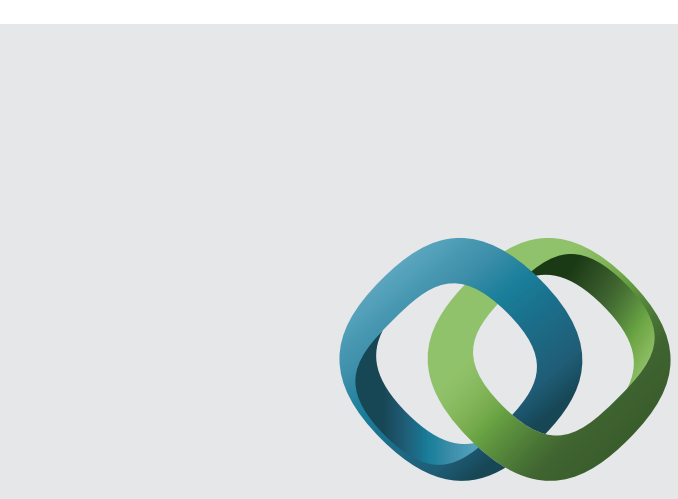

\section{Hindawi}

Submit your manuscripts at

http://www.hindawi.com
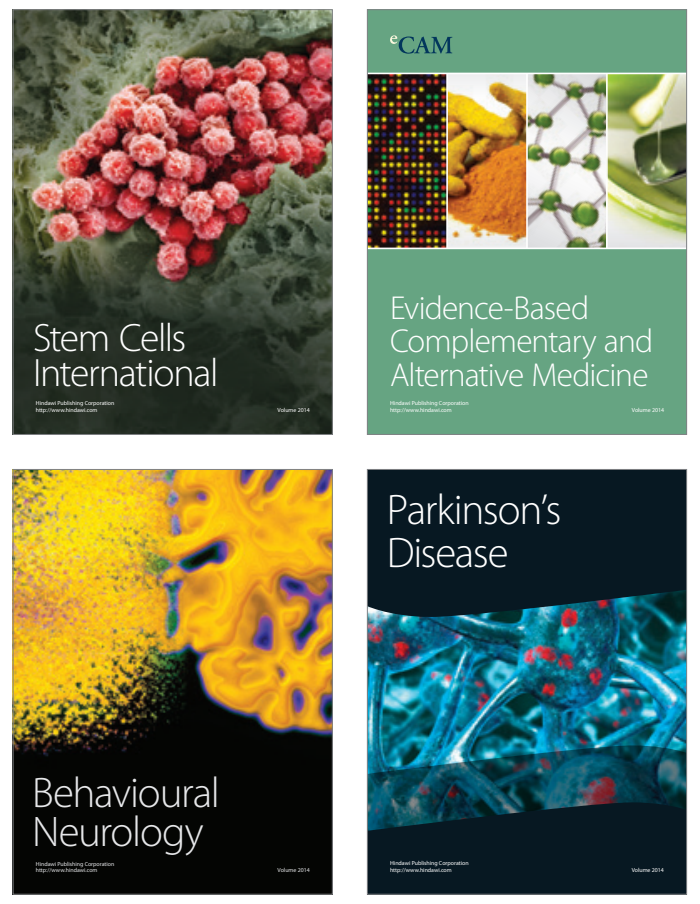
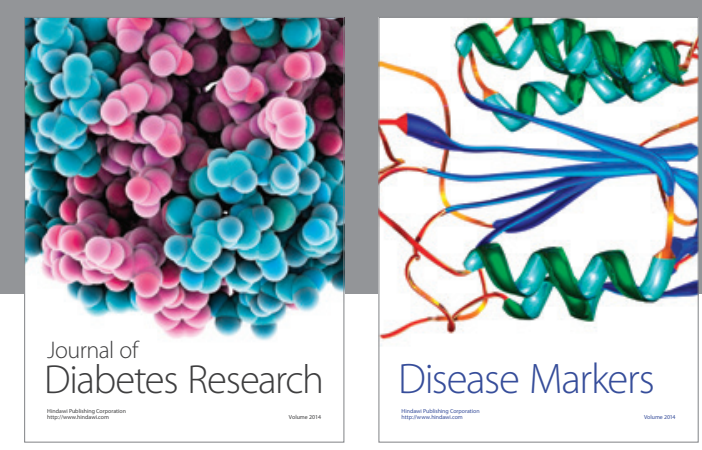

Disease Markers
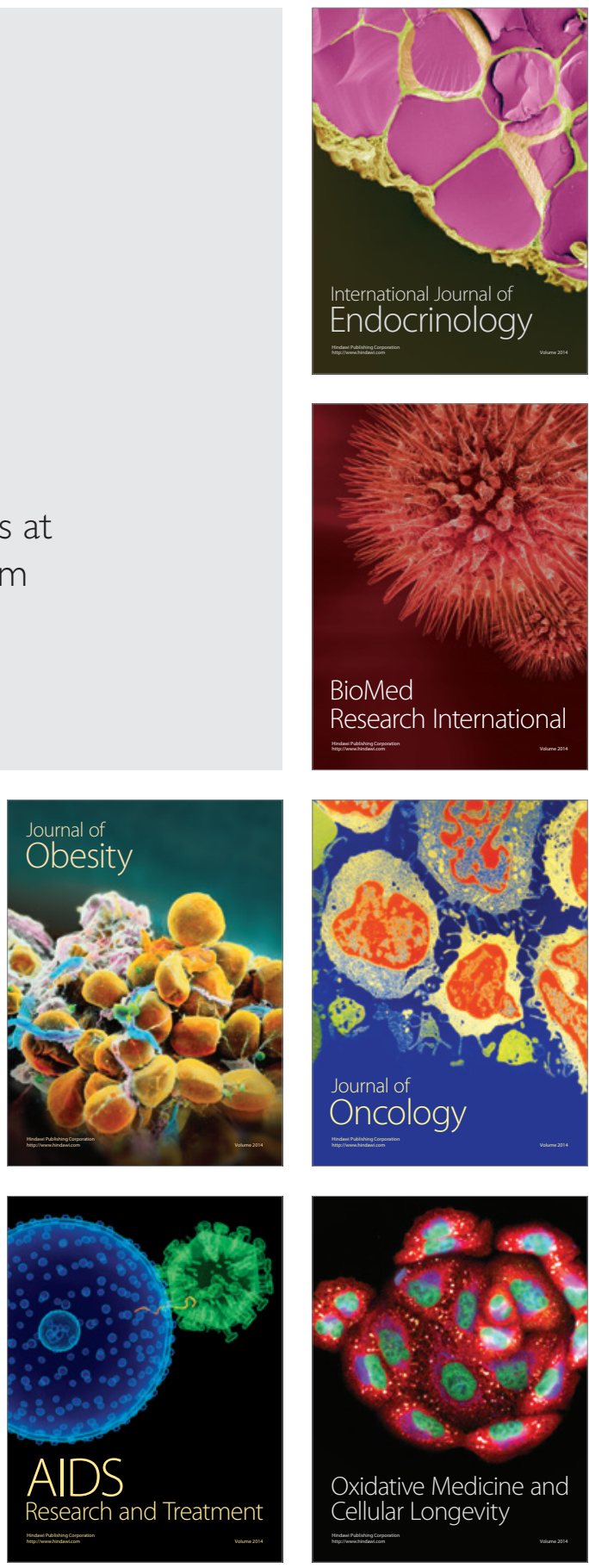